Beyond Philology No. 15/1, 2018

ISSN 1732-1220, eISSN 2451-1498

\title{
A school performance: \\ A teaching tool or real art?
}

KAROLINA JANCZUKOWICZ

Received 10.01.2017,

received in revised form 15.03.2018, accepted 20.03.2018.

\begin{abstract}
The article addresses the question of whether in using a school performance as a tool in ELT it is possible to achieve true artistic effects through it. It analyses the problem from the point of view of focusing on the value of the outcome rather than just the process of implementing theatre in ELT. The issues are discussed according to Bruner's criteria (1971) of artistic experience and Wenzel's conditions (2001) for authenticity in speaking in an ELT classroom. Furthermore, the notion of cognitive appeal is put forward as a key feature in achieving a shift in students' attitude towards performing, which may in turn result in achieving a truly artistic effect.
\end{abstract}

\section{Keywords}

artistic experience, authentic speaking, automatic speaking, amateur production, cognitive appeal 


\title{
Szkolne przedstawienie: \\ narzędzie w nauczaniu czy prawdziwa sztuka?
}

\begin{abstract}
Abstrakt
Artykuł odnosi się do kwestii wykorzystania przedstawienia szkolnego w nauczaniu języka angielskiego i czy dzięki niemu można osiagnác prawdziwie artystyczny efekt. Omawia ten problem $z$ punktu widzenia skupiania się na wartości efektu końcowego a nie na samym procesie wdrażania teatru jako narzędzia. Kwestie te sa omawiane w odniesieniu do kryteriów przeżycia artystycznego Brunera (1971) oraz do warunków autentyczności mówienia w nauczaniu języka angielskiego przedstawionych przez Wenzla (2001). Ponadto jako kryterium kluczowe przedstawione jest pojęcie apelatora poznawczego. Pojawienie się jego właśnie może skutkować zmiana nastawienia uczniów do wystawianej sztuki, a co za tym idzie dzięki niemu można osiagnąć efekt naprawdę artystyczny.
\end{abstract}

\section{Słowa kluczowe}

doświadczenie artystyczne, mówienie autentyczne, mówienie automatyczne, przedstawienie amatorskie, apelator poznawczy

\section{Introduction}

A need for adding a "creative aspect" to a regular classroom experience has been articulated for many years. However, it is usually expected to materialise in forms that merely break up the classroom routine so as to force students to have a fresh outlook on the learning material. In this way it is hoped that they are able to see the whole process of learning in a new light and become more active participants in the process. ${ }^{1}$ Furthermore, the accepted viewpoint seems to be that for the sake of learning a second language it is the process, i.e. rehearsals, rather than the final outcome, that is most valuable when it

\footnotetext{
1 Piasecka, Liliana (2017). "Creativity and foreign language learning". Paper delivered during PASE conference in Gdańsk on 23.06.2017.
} 
comes to ELT objectives (Maley and Duff 1978: 104). The following discussion attempts to change this perspective on the phenomenon of using theatre in ELT.

The phrase creative aspect of learning may have a direct reference to those elements that deal with an appreciation of art, where a huge potential lies in using prose, poetry or drama as authentic resources. If the choice of such materials matches the linguistic capabilities of students, a teacher may bring about a moment of true artistic discovery in some of the students. Bruner (1971: 87) presents four aspects of artistic experience; namely, (1) a synergy of experiences through understanding a work of art, (2) an effort that we make to grasp it, (3) being emotionally "moved" by it and (4) the question of the universal understanding of what we might consider as beautiful. When trying to apply his distinction to an ELT classroom, the criteria of (2) and (3) seem most relevant in this context, but, as will be revealed later, all four criteria can be involved when using works of art in teaching English.

\section{A school performance as a true artistic experience}

As far as the criterion (2) is concerned, the effort to grasp the artistic significance of a work of art can form a synergy with the intellectual effort to linguistically comprehend a poem, a piece of prose or a play. Seen in this perspective, staging a play becomes potentially even more rewarding than the other artistic forms mentioned, as the intellectual effort of overcoming linguistic difficulties is combined not only with the artistic element, but also with the actual physical effort of performing in all its complexities. It then becomes easier to experience Bruner's criterion (3), namely, the emotional involvement, as well as the experience of beauty thanks to it (criterion 4). Needless to say, the synergy of different experiences (criterion 1) becomes an even stronger element not in spite of but because of the fact that it is channelled through a second language and not a mother tongue. 
Naturally, there remains the question of the general purpose of such an activity; if our aim is art, part of the answer has already been given; it is possible to appreciate a piece of literature because of the effort that we make to achieve it, the emotional involvement in the process of discovering its significance, the sense of beauty that it may give us and a synergy of experiences that are involved in grasping it. If, however, we stage a play with a group of English learners in order to teach them English, what do we actually aim at? A likely response to that question is that through memorising the script, students can perfect their pronunciation, expand vocabulary or practice certain set phrases, by repeating language chunks. However, one potential teaching aim that does not appear as the most obvious, may turn out to be one of the greatest linguistic benefits of setting up a school performance, namely, speaking.

\section{A school performance as a speaking activity}

A performance of a play may not seem to be the most obvious example of a way to teach speaking in a second language. What we usually understand by true speaking is what Wygotski (1989) has described as a situation where an utterance is constructed as the thoughts are being formed in the mind of the speaker. However, from the point of view of using a second language, we cannot perceive all spoken utterances as either completely real (i.e. authentic), or artificial (i.e. automatic). When learning to speak in a foreign language we usually move along a spectrum from simpler, more automatic language to more complex and more authentic expressions. Wenzel (2001) presented five criteria, according to which we could judge the nature of a particular spoken utterance in an ELT classroom:

(1) the degree of the teacher's control over the content of the utterance,

(2) the presence or absence of the message in the exercise,

(3) the degree of the student's spontaneity and free will to speak, 
(4) the extratextual circumstances of interaction,

(5) the student's mental involvement in the content of the utterance, i.e. the degree of its cognitive appeal.

(Wenzel 2001: 62-63)

If we apply these criteria to a school performance, we can see to what extent it has the potential for authentic speech. In Wenzel's understanding of these criteria, they should be regarded independently (Wenzel 2001: 63), so even though the first criterion seems to disqualify a performance, as the written script leaves the student with no choice as to the content of what he or she says, there are still other criteria to be considered. Moreover, even in this case, we should treat the question of content within the limits of the convention of a theatre play, so the interpretation of the character, the choice of costume, the sound and other elements of an actual adaptation become as much a part of the content of the play as the script itself. Treated in this respect, a school performance does leave the actors with choice as to the content.

As far as the presence of the message is concerned (criterion 2 ), it depends largely on how the play is directed. If the teacher/director focuses on the linguistic aspects, such as pronunciation, then the language and not the message of the play will become the centre of attention. ${ }^{2}$ If, however, it is clear to the participants that the goal of the event is the play itself, then the attention is shifted to the message. This criterion is directly related to the criterion 5, "the mental involvement in the content", as it also largely depends on the extent to which the teacher directs the participants' attention to it. ${ }^{3}$

The remaining criteria - (3) student's spontaneity and (4) the extratextual circumstances - depend on yet another circumstance that remains for the teacher to ensure during the

2 For a more detailed description of ways in which a school performance can be used to teach linguistic aspects, such as pronunciation, see Janczukowicz (2014: 127-132).

3 This element, however, will be separately discussed in section 6 , devoted to the role of "cognitive appeal" in achieving artistic effects. 
production. The circumstance in question is the extracurricular nature of participating in the play and the addition of various elements that normally appear during a professional production (Janczukowicz 2014: 122-127). Spontaneity can become a very natural aspect of the production of the play if the student joins the performance on a voluntary basis; furthermore, the extratextual circumstances turn it into a real performance, as long as this is taken to mean not only free will on the part of the actors, but also a professional stage, lighting, costumes, etc. as well as the audience's reception of the play.

Consequently, although it is impossible to guarantee that a school performance will always be an example of authentic speech, it can become so, depending on the way in which it is directed, the physical reality in which it is performed, and the general attitude of the participants.

\section{A school performance as an example of an amateur production}

One may wonder whether, given the Polish reality, it is possible to achieve the conditions described above. The accepted expectations of the potential recipients of any form of art is that it is done either by "professionals", i.e. people with a degree in a particular discipline, or done as an exercise, either in cultural centres or as a school activity. In the second instance, it is usually only watched by school or family members, and only because of the fact that it has been done in that particular place or performed by those exact people. If this particular piece of art had been created anywhere else, by anyone else, the audience would not have attended that event. As a result, most artists who do not have appropriate qualifications, either because they have a different profession or, as in our case, because they are still young students - too young to have any degree - find it extremely hard to obtain an audience for their work. 
The situation appears even more difficult in the case of a play in English as the language barrier makes it even harder to find someone willing to watch a play for its own sake. However, this is not always the case, as English speakers (either native speakers or simply people well acquainted with AngloSaxon culture) are much more familiar with the convention of an amateur production. The phrase may refer to a whole range of activities, but in this paper it will be understood as a nonprofit event that involves a mix of both professionals and amateurs. In reality, it very often involves people whose passion or hobby is a particular field of art and who aim to master the technique through cooperation with people educated in the field. Such productions may involve not only theatre but also music, ballet or dance groups and are a fairly common phenomenon in English speaking countries.

The English adjective amateur can have positive associations which focus on the fact that something is done for love or without payment (e.g. an amateur sportsman) in contrast with the clearly derogatory adjective amateurish (e.g. her amateurish interviewing technique), ${ }^{4}$ indicating a lack of professionalism. Interestingly enough, the Polish adjective misses this distinction and is left with only one option amatorski, which covers both meanings. However, both positive and negative associations are present in other derivatives, e.g. amator meaning an amateur with a mild positive implication and clearly negative amatorszczyzna indicating the quality of being amateurish.

The conclusion that can be drawn from the discussion above is that although amateur performances are more common in English-speaking countries than in Poland, the potential for their place in the lives of ordinary people is present in Poland as well. Moreover, it could be through plays in English that the very idea stands a chance of being successfully im-

4 All the examples are taken from The New Oxford English Dictionary (1998). 
plemented in Poland, since such productions already are so much more a part of Anglo-Saxon culture.

Furthermore, when it comes to acting, all instances of professionalism are intermingled with amateurism since a professional actor is not always a professional singer or athlete at the same time. This mixture of professionalism and amateurism in many fields and at many levels is best exemplified in Polish amateur theatre productions in English, where a native speaker of English (in a way "a professional speaker of English") is an amateur actor while a professional Polish actor who has joined the group may not be fully proficient in English. The same may be said of dancers who have to sing and singers who dance. The diversity of the levels of expertise presented by the participants is an inevitable part of all theatre, both professional and amateur. However, it is in the amateur productions that it is more or less expected and the audience, which is acquainted with them, has come to accept this "unevenness" as a part of the convention. Having accepted it, members of the audience can appreciate such a play as a true piece of art according to all four criteria stipulated by Bruner (1971).

\section{The acting reality in a classroom situation}

What has been said earlier about amateur plays appears in the context of school performances to be almost like unrealistic idealism. Students' deficiencies in certain vital skills, such as articulation of speech or general acting skills make some teacher-directors give up from the start. They end up focusing on teaching English and involuntarily turn their play into an extended English lesson. ${ }^{5}$ Each play is an individual matter

5 As far as directing is concerned, an awareness of technical elements that make a play accessible to the audience, such as movement on stage, the need for certain tempo or an ability to control it, etc. are very helpful. However, what makes the difference between directing a professional play and a school performance is that the work with students involves discovering artistic talent and revealing potential acting skills. In this way, a teacher- 
taken up by a unique cast of actors, so it is impossible to make valid generalisations. However, there are certain factors that make it more likely to bring out the most talent in the students and, consequently, which may result in a true artistic experience for both - the actors and the audience.

One of the most important elements that enables students to become actors is making all aspects of the performance as real as possible. This means involving students in staging, lights, props and costumes. The less "lesson-like" the rehearsals are, the more likely the students are to develop true involvement in the personality and the story of their character. If, on the other hand they are made to practice their lines in their own English classroom, moving very little and only pretending to be holding objects or doing something, e.g. pretending to be drinking from imaginary cups, writing with imaginary pens etc. they will emotionally remain only students who pretend to be actors.

Looking back at Wenzel's criteria for achieving authenticity in classroom speaking activities, which were discussed in Section 3 , criterion 4 - the extratextual circumstances of interaction - become particularly relevant. Not only speech as a classroom activity, but also speech in other aspects, such as the performance of a play, will largely depend on the external circumstances. The physical space in which the text is being delivered, the actor's awareness of the audience's ability to understand what is being said, the tangible objects that the actors are holding or even the costumes that they are wearing, all contribute to the actor's sense of the authenticity (rather than the artificiality) of the situation.

For the sake of achieving such authenticity, it is really helpful to remove the scripts from the rehearsals as soon as possi-

director also becomes an educator. Still, rehearsals can seldom be transformed into a full scale acting workshop so the practical side frequently forces such a director not only to build on whatever hidden talent he or she has discovered, but also to skilfully hide students' deficiencies. Consequently, perceptiveness in noticing students' potential and constant openness to their suggestions become very important features of the teacher-director's work. 
ble, even if the text is then delivered with more hesitation. The moment the students start establishing eye-contact with other characters, they become aware of the actual tensions and the relationships between them. Such a moment frequently coincides with an improvement in their acting. This 'stepping into the character' is, however, a very individual moment and should be supported by the teacher with the other elements already mentioned, such as the stage, the costumes and props. They all help the student-actors to become the characters they act. Furthermore, the stage-lights blind them a little, so after a moment of getting used to the light, students can focus on the stage reality more since they are not able to see the audience.

In order to illustrate how important it is to use such elements in a production, we can compare two photographs of the same moment in one play 6 conducted on two different types of stage. Photograph 1 shows a makeshift stage in a school library and Photograph 2 a professional stage.

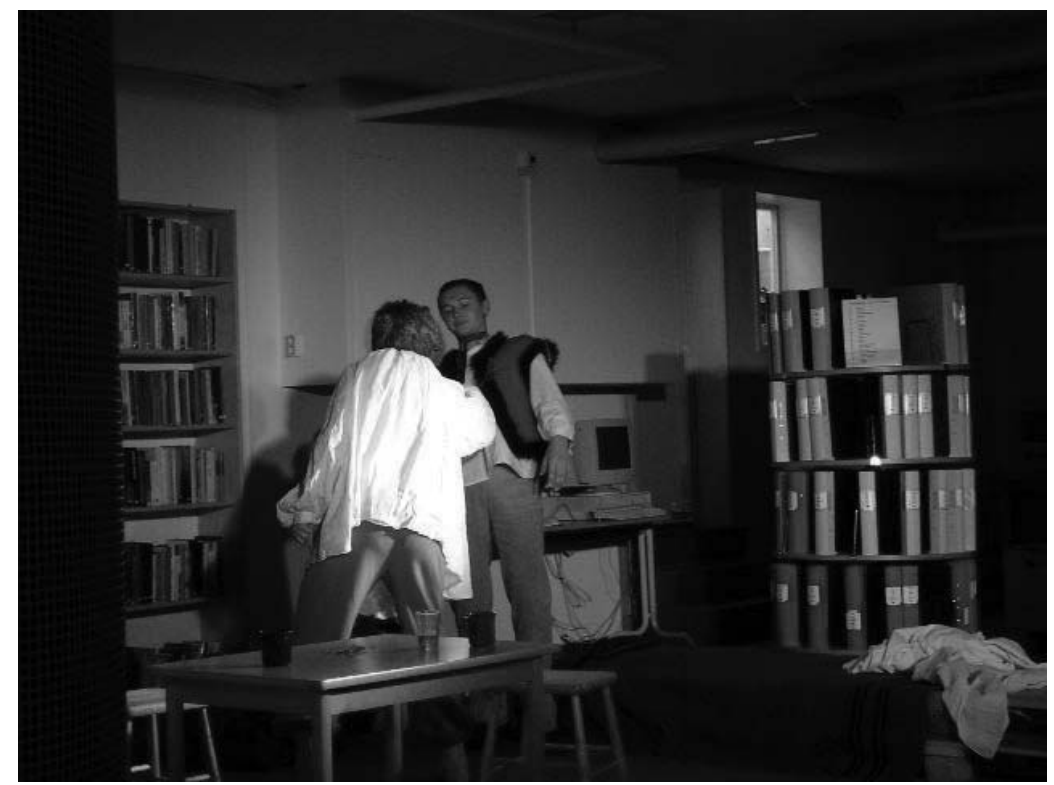

Photograph 1

${ }^{6}$ In the Shadow of the Glen by J. M. Synge (2002). Performance directed by Karolina Wenzel. Elblag: Teatr Dramatyczny; Ronneby; Sweden: Knut Hahnskolan. Photographs are taken from the author's private collection. 


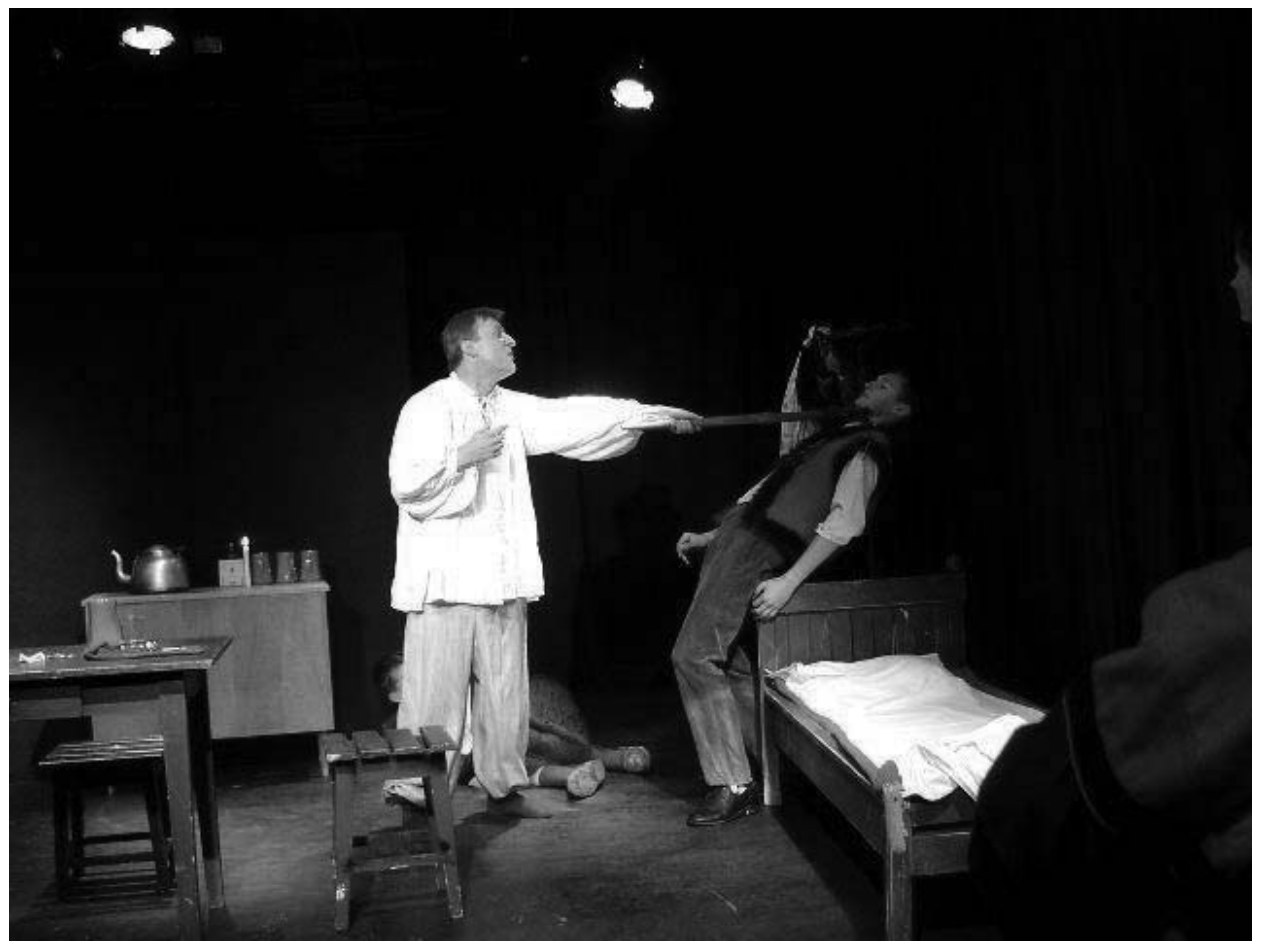

Photograph 2

Although the two photographs clearly present the same moment of the play, the crucial elements (props and stage lights) mentioned earlier, are missing from the first picture, while many distracting elements are present instead. The computer and the books in the background of photograph 1 distract the audience's attention, light coming from the window dissipates the light that falls on the actors while the furniture and the glasses visible in photograph 1 seem makeshift as they are more modern than the content of the play or the costumes would indicate. Consequently, it is much easier to focus one's attention on the people visible in photograph 2 than in 1 and for them it is much easier to create a stage reality in which they forget that they are students (or teachers) of English. This in turn can enable them to step into the parts they play and in this way they become real actors.

Nevertheless, it is equally important to mention one other factor invisible in both pictures; namely, the audience that was there and could follow the play in both cases. It was thanks to 
their responses, heard or "sensed" during both performances, that the play became an authentic experience for the actors. The audience is the factor that can tip the balance one way or the other in spite of the fact that, ideally, the actors should not see it. Part of the actors' minds will be acutely sensitive to minute signals that will indicate whether their audience understands the action and what their emotional response is. Professional actors are also sensitive to the audience's reception, but their experience and skill usually allow them to perform well regardless of such signals. For amateur actors, the audience's reception becomes the factor that can either make or mar the performance, and in this way it is the final feature that can transform an English lesson into a true amateur production.

\section{Cognitive appeal as a factor in building the authenticity of the play}

So far, several factors have been mentioned which are likely to contribute to the authenticity of the theatre experience. The aspect that should still be discussed is the relation of the students to the content of the play. Unlike the previously discussed factors, the success of which is within the control of the teacher, the relationship between the students and the text is a much more individual and even personal matter. It can be twofold; namely, either the students will remain emotionally uninvolved and will treat it as yet another teaching material, or their attention may become so focused on the fictional reality created that the stage becomes an actual space, while the feelings become true emotions in the same way that professional actors utilise their own emotions to express those of the characters they play. If that happens, the play becomes not only an authentic speaking experience but it also becomes an artistic experience.

In order to achieve that shift in the focus of attention, one factor must be added to the elements described in the previous 
sections; namely, the factor of cognitive appeal. Wenzel describes it as "the appeal of the context of the text to the cognitive structure of the student which leads to changes in the structure and results in true learning process" (2001: 27). When describing it, he also mentions the shift in focus from participating in a language lesson to the content of the text (2001: 26). It can also be defined as "a quality of a given text or utterance that influences the cognitive processes in the student's mind in an authentic manner" (Aleksandrowska 2015: 57). Although this notion usually appears in the context of using language materials in an ELT classroom ${ }^{1}$, it is also a vital element that is decisive as to the nature of the students' attitude towards the play in which they are performing.

Firstly, the necessity of the shift of attention is present in both situations. Apart from all the external factors, which may or may not bring about this change of attitude, it is the content of the play that will determine it. The student-actors may find actual pleasure in enacting the story, emotions and speech of their characters. Once they do, everything they say becomes their own. Furthermore, when they say 'their own' text, it changes their cognitive structures and, as a result, becomes a true learning process. However, certain conditions need to be met in order for the content of the play to be appealing at the cognitive level. Rychło (2008: 72) mentions three; namely, the focus on the content, an inspiration for discussion or reflection, and reference to an issue important for the student. Needless to say, all three conditions are interdependent. If the matter of the play is important for the students, it will be more likely to inspire true reflection. Then the student stands a greater chance of shifting his attention to the content, and away from the fact that the whole process involves learning English in a way.

1 Wenzel (2001), Rychło (2008), Janczukowicz (2011) and Aleksandrowska (2015a, 2015b). 


\section{Concluding remarks}

While most people would admit that using theatre can be beneficial for learning English, the way to obtain these learning benefits is not obvious. For many teachers and ELT scholars (e.g. Maley and Duff 1978), it will be the focus on the process of staging the play rather than the final outcome that can bring about the most important learning benefits. As far as such aspects of learning a second language as vocabulary, pronunciation or even speaking skills are concerned, they may be right. However, when we attempt to engage the less tangible but still crucial factors that contribute to the overall success of learning a second language, such as motivation, emotional and personal involvement (Daszkiewicz 2015: 107) or long term memory, it is the focus on the actual play and having real art as the goal that can achieve this success. Interestingly enough, aiming at a true artistic performance does not happen at the expense of the more 'basic' educational goals. On the contrary, a certain synergy appears, because the students speak in a more authentic way, remember the vocabulary better and may practice pronunciation with greater determination and perseverance.

All in all, a certain paradox appears; in order to achieve better artistic results, the students must 'forget' that they are taking part in an English language activity. It is thanks to this that they emotionally engage in the play better, and, as a result, any language learning that takes place then becomes far more effective. Consequently, when trying to answer the question of whether school performances are only teaching tools or real art, one has to admit that under certain conditions they can become pieces of art, but only when they reach that point, do they become most successful as teaching tools. 


\section{References}

Aleksandrowska, Olga (2015a). The Educational Potential of Texts of Culture in Teaching English to Senior Secondary School Students. Frankfurt am Main: Peter Lang.

Aleksandrowska, Olga (2015b). "Texts of culture in English language education". In: Karolina Janczukowicz, Mikołaj Rychło (eds.). General Education and Language Teaching Methodology: The Gdańsk School of ELT. Frankfurt am Main: Peter Lang, 135-146.

Bruner, Jerome S. (1971). O poznawaniu: Szkice na lewa rękę. Warszawa: Państwowy Instytut Wydawniczy.

Daszkiewicz, Michał (2015). "Expressing knowledge as a personal educational event". In: Karolina Janczukowicz, Mikołaj Rychło (eds.). General Education and Language Teaching Methodology: The Gdańsk School of ELT. Frankfurt am Main: Peter Lang, 95110.

In the Shadow of the Glen by J. M. Synge (2002). Performance directed by Karolina Wenzel. Elblag: Teatr Dramatyczny; Ronneby, Sweden: Knut Hahnskolan.

Janczukowicz, Karolina (2011). "Cognitive appeal as a criterion in the choice of teaching materials". Beyond Philology 8: 155-166.

Janczukowicz, Karolina (2014). Teaching English Pronunciation at the Secondary School Level. Frankfurt am Main: Peter Lang.

Maley, Alan, Alan Duff (1978). Drama Techniques in Language Learning. Cambridge: Cambridge University Press.

Rychło, Mikołaj (2008). The Educational Approach to Language Teaching. Warszawa: Wydawnictwo Naukowe PWN.

The New Oxford Dictionary of English (1998). Oxford: Oxford University Press.

Wygotski, Lew (1989). Myślenie i mowa. Trans. Edda Fleszerowa, Józef Fleszer Warszawa: Państwowe Wydawnictwo Naukowe.

Wenzel, Ryszard (2001). The Education of a Language Teacher. Gdańsk: Wydawnictwo Uniwersytetu Gdańskiego. 
Karolina Janczukowicz ORCID iD: 0000-0001-8933-7088 Instytut Anglistyki i Amerykanistyki Uniwersytet Gdański ul. Wita Stwosza 51 80-308 Gdańsk

Poland

karolina.janczukowicz@univ.gda.pl 